\title{
Kassavirtojen hallinta maitotiloilla
}

\author{
Antti Partanen², Seppo Mönkkönen ${ }^{1}$, Pirjo Suhonen ${ }^{1}$ \\ 1) Savonia-ammattikorkeakoulu, PL 72, 74101 Iisalmi, etunimi.sukunimi@ savonia.fi \\ 2) antti.partanen@poppankki.fi
}

\section{TIIVISTELMÄ}

Suomen lypsykarjatuotanto on siirtynyt entistä suurempaan kokoluokkaan ja siitä on tullut liiketoimintahakuisempaa yritystoimintaa. Tällöin yrittäjien taloudenhallinta taidot ja ammattitaito kannattavaan liiketoimintaan nousevat suureen rooliin. Maitokriisin vallitessa tilojen rahaliikennettä tulee seurata entistä lyhyemmällä tähtäimellä, koska maitotilojen tulot pienenevät merkittävästi vuonna 2015.

Tässä tutkimuksessa selvitettiin lypsykarjatilojen kassavirtojen hallintaa maksuvalmiuden näkökulmasta. Tutkimus toteutettiin kvalitatiivisena haastattelututkimuksena kuudelle maksuvalmiudeltaan eritasoiselle lypsykarjatilalle Pohjois-Savossa. Maksuvalmiutta selvitettiin tilavierailujen aikana tiloille laadittujen kassabudjettien ja teema-haastattelun avulla. Tarkoituksena oli tarkastella yrittäjien ammattitaitoa kassavirtojen hallinnan ja sekä yritysten tunnuslukujen avulla. Työssä haastateltiin kahta maatalouden talousasiantuntijaa, nämä haastattelut toimivat työssä katsauksena maitotilojen maksuvalmiuden nykytilanteeseen ja niitä peilattiin myös työn tuloksiin.

Tutkimus tuloksissa kuvattiin tilojen eroja tulojen ja menojen avulla jakamalla tilat maksuvalmiuden ja yrittäjien ammattitaidon perusteella kolmeen luokkaan: hyvä, keskiverto ja heikko. Luokittelu perustui ensisijaisesti yrittäjien ammattitaitoon. Työn alun hypoteesi, lypsykarjatilat eivät budjetoi, osoittautui paikkaansa pitäväksi. Lisäksi tilojen menojen suhde tuloihin vaikuttaa eniten yritysten maksuvalmiuden tasoon eikä niinkään tuotosmäärät. Tilojen suurimmat menoerät olivat rahoitus ja konekustannukset, joissa esiintyi myös suurimmat yllättävät menot.

Johtopäätöksenä tuloksista voi todeta, että tilojen kannattaa aloittaa aktiivinen budjetointi viimeistään nyt, koska maidontuotannon nykytila ja tulevaisuus eivät näytä kovinkaan valoisalta. Tutkimus todistaa myös sen, että yrittäjän ammattitaidolla on suuri merkitys maksuvalmiuden hallinnassa. Tutkimuksen luotettavuutta vahvistaa tulosten samankaltaisuus haastateltujen asiantuntijoiden mielipiteisiin. Budjetoinnin merkitys on tiedetty aina, mutta sitä ei ole tähän mennessä hyödynnetty riittävästi. Toivottavasti budjetointi tulee lisääntymään tämän maitokriisin aikana. Luotettavuutta heikentää hieman tilojen luokittelu, joka on tehty vain tämän työn tutkimustiloille. Tutkimuksessa mukana oleva joukko lypsykarjatiloja edustaa valveutuneita yrittäjiä verrattuna keskimäärin Suomen maitotilallisiin, joten luokittelu ei voida käyttää esimerkiksi kansallisessa vertailussa, vaan ennemminkin alueellisessa. Jatkotutkimuksessa voidaan esimerkiksi vertailla velallisten ja velattomien maitotilojen yrittäjien ammattitaitoa ja maksuvalmiutta. Samankaltaisen tutkimuksen voisi toteuttaa myös muille maatalouden tuotantomuodoille.

Asiasanat: maksuvalmius, kassavirta, lypsykarjatila, budjetti 


\section{Johdanto}

Maidontuotanto on yleisin maatalouden tuotanto muoto Suomessa. Lypsykarjatalous on ollut vahvaa kautta historian ja se menestyy tälläkin hetkellä parhaiten suomaisista maaseutuelinkeinoista. Maidontuottajia on tällä hetkellä noin 8700 ja tiloilla on keskimäärin 31 lypsylehmää. (Kiviranta, 2013) Tilojen määrä vähenee vuosittain, mutta vastaavasti kehittyvien tilojen tuotanto laajenee. Kehittyvät tilat kompensoivat lopettaneiden kohdalla, eli tuotetun maidon määrä Suomessa pysyy suunnilleen samalla tasolla, eli nykyisessä 2242 miljoonassa litrassa/vuosi. Vahvimpina maidontuotannon alueina Suomessa ovat Pohjois- Pohjanmaa, Pohjois- Savo ja Pohjanmaa. Maidontuotanto on kohdentunut näille alueille, koska alueet ovat ilmastoolosuhteiltaan otollisimpia nurmen viljelyyn, mikä on lypsylehmän pääravinnon lähde. Suurimpia maidontuotannon paikkakuntia ovat Kokkola, Kuopio ja Kiuruvesi, jotka sijoittuvat C- tukialueelle. Maidontuotanto on Suomessa myös merkittävä työllistäjä ja veronmaksaja, joten sen kansantaloudellinen merkitys on suuri. (Vuorisalo, 2014)

Suomalainen maatalous elää tällä hetkellä murroksen aikaa. Markkinoiden muutokset ja vallitseva epävakaa geopoliittinen tilanne ovat aiheuttaneet haasteita useiden tilojen kohdalla. Päätuotteiden ja tuotantopanosten hintojen heilahtelut ovat luoneet haastavammat toiminta- olosuhteet yrittäjille. Tämä on iskenyt etenkin lypsykarjatilallisiin, joihin esimerkiksi geopoliittinen Ukrainan kriisi vaikuttaa voimakkaimmin pakotepolitiikan kautta. EU:n maataloustukien maksatuksen siirtyminen tuo myös haasteita lypsykarjayrittäjien talouden hallintaan ja rahan riittävyyteen. Tällöin nousee esiin yrittäjän ammattitaito, jolla luodaan pohja koko yrityksen toiminnan jatkuvuudelle tulevaisuudessa.

Yrittäjien taloudenhallinta taidot vaihtelevat paljon maitotilallisten välillä. Taloudenhallinta on osa yrittäjän ammattitaidon kokonaisuutta ja vaikuttaa todella paljon tilan toimintaan joka osa- alueella. Tilan pito vaatii pitkäntähtäimen suunnitelmallisuutta ja suunnitelman seurantaa. Tämän lisäksi tulisi vielä päivittää laadittua suunnitelmaa seurannan avulla tarpeen mukaan. Esimerkiksi tulojen ja menojen ennalta suunnittelulla saadaan yleensä hyviä lopputuloksia. Moni yrittäjä elää kuitenkin hetkessä, eli suunnittelee talouttaan vain lyhyellä tähtäimellä. Tilanpitäjät keskittyvät ennemmin käytännön töihin kuin talouden suunnitteluun ja kirjanpidon laadintaan. Käytännön töiden huolellinen tekeminen on järkevää, mutta talouden suunnittelun laiminlyönti voi johtaa tulevaisuudessa ongelmiin, esimerkiksi rahan loppumisen myötä. Tilan tuotannon kehittäminen myös vaikeutuu, jolloin rahaliikenne varmasti hidastuu tulevaisuudessa. Rahan vähentymisen myötä voi tulla maksuvalmiusongelmia, jotka taas pitkällä ajalla vaikuttavat negatiivisesti yrityksen kannattavuuteen sekä varallisuuteen. Tämä taas johtaa tuotantopanosten ostojen vähentymiseen ja sitä kautta tuotannon heikkenemiseen.

\section{Aineisto ja menetelmät}

\section{Tavoitteet}

Opinnäytetyöllä haettiin ratkaisua ja vastauksia ydinkysymykseen, kuinka maidontuottajat ymmärtävät yrityksensä kassavarojen liikkuvuuden ja millainen vaikutus sillä on tilan maksuvalmiuteen. Työn tuloksilta odotettiin tietoa siitä, miten lypsykarjayrittäjät osaavat suhteuttaa tilansa tulot ja menot kassavirran hallinnan näkökulmasta. Millä keinoilla lypsykarjatilalliset hallitsevat maksuvalmiuttaan ja mitä työkaluja he tarvitsevat sen parantamiseksi? Näistä lähtökohdista haastatteluihin lähdetään.

Haastattelulla ja laskentatyökalun esittelyllä pyrittiin selvittämään ongelmakohtia, joita tilojen maksuvalmiudessa mahdollisesti ilmenee. Tarkoituksena oli löytää ratkaisuja ilmeneviin ongelmiin, joita voitaisiin tarjota tiloille tulevaisuudessa, esimerkiksi maatalouden neuvonnan ja tiedottamisen kautta. Toimeksiantaja taas voi käyttää hankittua tietoa esimerkiksi ennaltaehkäisemään asiakkaidensa maksuvalmiuden heikentymisen riskien hallinnan avulla. Muita hyödynsaajia toimeksiantajan lisäksi voivat olla esimerkiksi oppilaitos, neuvontaorganisaatiot, opiskelijat ja tietenkin maatalousyrittäjät.

Viljelijöitä haastateltiin tilakäyntien aikana ja selvitetään esimerkiksi, kuinka tarkasti he laativat budjettinsa vuosi- ja kuukausitasolla tai laativatko ollenkaan. Haastatteluissa selvitettiin myös, miten he seuraavat budjetin toteutumista ja kuinka he reagoivat kassavirran muutoksiin. Lisäksi heille esiteltiin oppilaitoksen laatimaa valmista vuosibudjetointityökalua, jonka he saavat käyttöönsä. Työkalun avulla he voivat tulevaisuudessa suunnitella ja kartoittaa tilansa maksuvalmiutta paremmin.

Esimerkkinä ongelmatilanne, jossa viljelijä on suunnitellut maksavansa väkilannoitelaskun viljoista saatavilla myyntituloilla sadonkorjuun jälkeen. Kasvukauden satotaso jää kuitenkin paljon odotettua 
heikommaksi sääolosuhteiden vuoksi ja siitä saatava tulo ei riitä kattamaan lannoitelaskua. Tällöin tulee tilanne, jossa viljelijän on reagoitava kassavirran yllättävään muutokseen. Hänen täytyy tehdä muutoksia yrityksensä budjettiin ja etsiä lannoitelaskuun menevä raha jostain muusta tulo- tai rahoituslähteestä. Jos hänen loppuvuoden tulot on jo budjetoitu muihin menoihin eikä ylimääräistä rahaa ole käytettävissä laskun maksuun, niin hän kääntyy esimerkiksi rahoituslaitoksen puoleen ja pyytää lyhytaikaista luottoa laskun maksamiseen. Tällainen on yksi esimerkki tilanteesta tilan talouden hallinnassa, jota opinnäytetyön avulla kartoitettiin ja pyritään ennaltaehkäisemään tulevaisuudessa. Kyseiset tilanteet tulevat myös pankille yllätyksinä ja ovat lisääntyessään riski pankin liiketoiminnassa asiakkaan maksukyvyn heikkenemisen myötä. (Halonen, 2014)

\section{Toteutus}

Lypsykarjatilallisten haastattelut toteutettiin kuudelle maksuvalmiudeltaan eritasoiselle tilalle kvalitatiivisen haastattelututkimuksen keinoin. Tilat käsiteltiin raportissa yksi tila kerrallaan kokonaisuutena. Työvaiheet etenivät suunnittelusta ja budjetin laadinnasta haastatteluun, jonka jälkeen saatu materiaali purettiin litteroimalla ja analysoimalla tilan maksuvalmiutta ja tämän talouden osa-alueen hallintaa kartoittamalla. Tilavierailun aikana budjetin käsittely ja haastattelu jaettiin omiksi osioiksi, ja ne myös raportoitiin erikseen omista näkökulmista. Budjetin käsittelyn tarkastelu näkökulma raportoitiin laaditun budjetin ja numerotiedon perusteella ja haastattelu osiossa tarkasteltiin yrittäjän ammattitaitoa maksuvalmiuden hallinnassa.

Opinnäytetyö toteutettiin pääasiassa kenttätutkimuksena jalkautumalla maitotiloille. Iso osa työajasta kului tilakäyntien ympärille, niiden suunnitteluun, toteutukseen ja raportointiin. Työhön lähdetään ongelmaratkaisu näkökulmasta. Ongelmakohdat ja riskitekijät kassavirtojen hallinnassa kartoitettiin haastattelujen avulla, joista tehtiin yhteenveto ja etsittiin keinoja, joilla maksuvalmiusongelmia saataisiin ennaltaehkäistyä.

\begin{tabular}{|c|c|c|c|c|c|c|c|c|c|c|c|c|c|c|c|}
\hline Kassameno/-tulo & alv\% & Tammi & Helmi & Maalis & Huhti & Touko & Kesä & Heinä & Elo & Syys & Loka & Marras & Joulu & Yhteensä| & Vertailu \\
\hline Alkukassa & & 20000 & 27681,03 & 34056,67 & 30160,34 & \begin{tabular}{|l|}
$-244,9933$ \\
\end{tabular} & -337 & 3026 & 3158 & 1450 & -4915 & -9544 & -10588 & & tieto \\
\hline Kassatulot: Maidon myynti & 14 & 17304 & 19357 & 14000 & 14350 & 16743 & 15400 & 15750 & 14875 & 15050 & 14175 & 14175 & 14350 & 185529 & 222750 \\
\hline Maidon tuet & & 3667 & 3649 & 3560 & 3649 & 3649 & 3916 & 4005 & 3783 & 3827 & 3605 & 3605 & 3649 & 44562 & 44055 \\
\hline Välitysvasikat ja teuraat & 24 & & & & 2000 & & & 1000 & & 7000 & & 1000 & & 11000 & 10000 \\
\hline Pelto- yms. suorat tuet & & 3000 & 4500 & & & & & & & & 10000 & 3500 & 25000 & 46000 & 57500 \\
\hline Muut tulot (urakointi) & 24 & & & & & & 3000 & & & 2000 & & & & 5000 & 5000 \\
\hline Alv.n ja muu veronpalautus & & & & 1000 & & & & & & & 2500 & & & 3500 & \\
\hline Korko yms. tulot & & & & & & & 1000 & & & & & & & 1000 & 2500 \\
\hline Lainojen nostot & & & & & & & & & & & & & & 0 & \\
\hline Metsätulot & 24 & & & & & & & & & & 5000 & & & 5000 & \\
\hline Yksityistalouden tulot & & & 1000 & 1000 & & & & & & & & & & 2000 & \\
\hline Myyntien alv $24 \%$ & & 0 & 0 & 0 & 480 & 0 & 720 & 240 & 0 & 2160 & 1200 & 240 & 0 & 5040 & \\
\hline Myyntien alv $14 \%$ & & 2423 & 2710 & 1960 & 2009 & 2344 & 2156 & 2205 & 2083 & 2107 & 1985 & 1985 & 2009 & 25974 & \\
\hline Käytettävissä olevat kassavarat & & 46393 & 58897 & 55577 & 52648 & 22491 & 25855 & 26226 & 23898 & 33594 & 33549 & 14960 & 34420 & 334605 & 341805 \\
\hline Kassamenot: Rehut & 14 & 5000 & 5000 & 5000 & 5000 & 5000 & 5000 & 5000 & 5000 & 5000 & 5000 & 5000 & 5000 & 60000 & 66000 \\
\hline Eläinten hankinta & 24 & & 1200 & & & & & & & & & & & 1200 & \\
\hline Eläinlääkintä & 10 & 110 & 110 & 110 & 110 & 110 & 110 & 110 & 110 & 110 & 110 & 110 & 110 & 1320 & 1200 \\
\hline Siemennys & 24 & 417 & 417 & 417 & 417 & 417 & 417 & 417 & 417 & 417 & 417 & 417 & 417 & 5000 & 5200 \\
\hline Muut kotieläintal. menot & 24 & 250 & 250 & 250 & 250 & 250 & 250 & 250 & 250 & 250 & 250 & 250 & 250 & 3000 & 4000 \\
\hline Sähkömenot & 24 & 800 & 800 & 800 & 800 & 800 & 800 & 800 & 800 & 800 & 800 & 800 & 800 & 9600 & 10000 \\
\hline Poltto- ja voiteluaineet & 24 & & & & 8000 & & & & & & 4000 & & & 12000 & 15000 \\
\hline Pellon vuokra & & & & & & 1000 & & & & & & & & 1000 & 1000 \\
\hline Lannoitteet ja kalkki & 24 & & & 4000 & 4000 & & & & & & & 4000 & & 12000 & 13200 \\
\hline Siemenet & 24 & & 2000 & 1000 & & & & & & & & & & 3000 & 2850 \\
\hline Palkkausmenot & & & & & & 2000 & & 2000 & 2000 & 2000 & & & & 8000 & 7500 \\
\hline Ostettu urakointi (konevuokra) & 24 & & & & & & & & & 4000 & 3000 & & & 7000 & 8000 \\
\hline Korjaus- ja huoltomenot & 24 & 600 & 600 & 600 & 4000 & 1000 & 2000 & 1500 & 3000 & 4000 & 3000 & 1500 & 500 & 22300 & 21000 \\
\hline Myel ja mata & & & 3400 & & 500 & & & & & 3400 & & & & 7300 & \\
\hline Muut vakuutukset & & & & 1000 & & & 3000 & & & 1500 & & 2000 & & 7500 & 7500 \\
\hline Muut wotuiset menot & 24 & 2917 & 2917 & 2917 & 2917 & 2917 & 2917 & 2917 & 2917 & 2917 & 2917 & 2917 & 2917 & 35000 & 36000 \\
\hline Muut menot alv 0\% & & 1250 & 1250 & 1250 & 1250 & 1250 & 1250 & 1250 & 1250 & 1250 & 1250 & 1250 & 1250 & 15000 & 20000 \\
\hline Rakennus- ja salaojitusinvest. & 24 & 1000 & & 600 & 1500 & 1000 & & 2000 & & 4000 & & & & 10100 & 10000 \\
\hline Koneiden hankinta & 24 & & & & & & & & & & & & 7000 & 7000 & 6000 \\
\hline Lainojen korot & & 304 & 304 & 304 & 2269 & 304 & 304 & 304 & 304 & 304 & 2269 & 304 & 304 & 7578 & \\
\hline Lainojen lyhennys & & 1418 & 1418 & 1418 & 13418 & 1418 & 1418 & 1418 & 1418 & 1418 & 13418 & 1418 & 1418 & 41016 & \\
\hline Metsätalouden menot & 24 & & & & & 500 & 500 & & & & & & & 1000 & \\
\hline Yksityistalouden menot & & 2500 & 2500 & 2500 & 2500 & 2500 & 2500 & 2500 & 2500 & 2500 & 2500 & 2500 & 2500 & 30000 & 30000 \\
\hline Ostojen alv $10 \%$ & & 11 & 11 & 11 & 11 & 11 & 11 & 11 & 11 & 11 & 11 & 11 & 11 & 132 & \\
\hline Ostojen alv $14 \%$ & & 700 & 700 & 700 & 700 & 700 & 700 & 700 & 700 & 700 & 700 & 700 & 700 & 8400 & \\
\hline Ostojen alv $24 \%$ & & 1436 & 1964 & 2540 & 5252 & 1652 & 1652 & 1892 & 1772 & 3932 & 3452 & 2372 & 2852 & 30768 & \\
\hline \multicolumn{16}{|l|}{$\begin{aligned} \text { Arvonlisäveron maksu } \\
\text { Ennakkoverot ja iälkiverorot }\end{aligned}$} \\
\hline Ennakkoverot ja jälkiverot & & & & & & & & & & & & & & 0 & \\
\hline Kassamenot yhteensä & & 18712 & 24840 & 25416 & 52893 & 22828 & 22828 & 23068 & 22448 & 38508 & 43093 & 25548 & 26028 & 346214 & 264450 \\
\hline Kassatulot - kassamenot & & 7681 & 6376 & -3896 & -30405 & -92 & 3364 & 132 & -1708 & -6364 & -4629 & -1044 & 18980 & -11609 & 77355 \\
\hline Loppukassa & & 27681 & 34057 & 30160 & -245 & -337 & 3026 & 3158 & 1450 & -4915 & -9544 & -10588 & 8391 & 8391 & \\
\hline
\end{tabular}




\section{Tutkimusmenetelmät}

Opinnäytetyö toteutettiin kvalitatiivisena tutkimushaastatteluna kuudelle eri lypsykarjatilalle. Tiedonkeruumenetelmänä toimi teemahaastattelu ja aineiston käsittely ja raportointi toteutettiin sisällönanalyysin avulla. Tilojen määrän valinta tutkimukseen perustui toimeksiantajan ja oppilaitoksen suositukseen. Otannaksi valittiin kuusi maksuvalmiudeltaan kolmeen luokkaan jakautuvaa tilaa. Tällä joukolla saatiin riittävästi vertailukelpoisia tuloksia, ja myös tekijän työmäärä ja resurssit pysyivät kohtuullisina. Sopivan kokoisella otannalla saavutettiin tiedon ja tulosten saturaatio, jossa tutkimustulokset alkavat toistamaan itseään, ja uutta tietoa tutkittavasti ilmiöstä ei enää saada (Tuomi;ym., 2012 ss. 87-88).

\section{Tulokset}

Tässä opinnäytetyössä tilat jaetiin ammattitaidon ja maksuvalmiuden perusteella kolmeen luokkaan: hyvä, keskiverto ja heikko. Jako perustui ensisijaisesti yrittäjien talouden hallinnan ammattitaitoon, jota selvitin haastattelun ja budjetin käsittelyn yhteydessä tekemäni havainnoinnin perusteella. Luokittelu tehtiin talouden operatiivisen ja strategisen hallinnan kokonaisuutena painottaen kuitenkin operatiivista kassabudjetoinnin näkökulmaa tutkimus asetelman mukaisesti. Strateginen eli pitkän aikavälin suunnitelmallinen talouden hallinta vaikuttaa oleellisesti yrittäjän ammattitaitoon, joten tämäkin näkökulma otettiin luokittelussa huomioon. Strategista suunnittelua tilan taloudessa on esimerkiksi suuret investoinnit, verosuunnittelu ja mahdollisen sukupolvenvaihdoksen suunnittelu. Operatiivista eli lyhyen ajan suunnittelua on esimerkiksi budjetointi ja ostokäyttäytyminen. Tilojen luokitteluun on myös huomioitu aikaisempi talouden hoito yhdessä rahoittajan kanssa. Luokkajako on toteutettu yhdessä pankin rahoitusasiantuntijoiden kanssa.

\section{Lypsykarjatilojen tunnusluvut ja maksuvalmius}

TAULUKKO 1. Tilojen perustietoja

\begin{tabular}{|c|c|c|c|}
\hline & Hyvä & Keskiverto & Heikko \\
\hline Lypsylehmien lukumäärä & 105 & 79 & 56 \\
\hline Peltopinta- ala (ha) & 123 & 90 & 103 \\
\hline Keskituotos (kg) & 9800 & 9150 & 10200 \\
\hline
\end{tabular}

Tilat jaettiin maksuvalmiudeltaan kolmeen eri luokkaan. Jokaisessa luokassa on kaksi tilaa. Oheisesta taulukosta (Taulukko 1) nähdään tilojen perustietoja. Luvut on esitetty keskiarvojen perusteella luokkien sisällä. Esimerkiksi hyvässä luokassa eläinmäärä on laskettu kahden tilan keskiarvon mukaan. Luvuista voidaan päätellä, että tutkimustilat ovat maamme keskiarvoja selvästi korkeammalla esimerkiksi eläinmäärän ja keskituotoksen osalta. Huomiona taulukosta 1 voisi todeta, että korkea keskituotos ei välttämättä kerro tilan hyvästä maksuvalmiudesta tai liiketoiminnan kannattavuudesta, jos esimerkiksi kulujen osuus on suuri. Korkean keskituotoksen omaavilla tiloilla voi olla myös liian kallis eläinten ruokinta, joka vähentää maidosta saatavaa tuloa kokonaisuudessaan.

Taulukosta 2 nähdään lypsykarjatilojen talouden tarkastelussa yleisimmin käytettyjä tunnuslukuja. Vertailuluvut on valittu luokkien keskiarvojen perusteella, kuten Taulukossa 1. Taululukossa on vertailtu erilaisia tunnuslukuja yritysten liikevaihtoihin, mikä on yleinen käytäntö yritysten tunnuslukujen tarkastelussa. Rahoittaja käyttää myös osaa kyseisistä vertailumalleista. Tässä tutkimuksessa tulee huomioida, että kaikilla tiloilla on melko paljon velkaa. Lopputulos olisi varmasti erilainen, jos mukana olisi velattomia maitotiloja. 
TAULUKKO 2. Yleisiä tunnuslukuja suhteessa liikevaihtoon

\begin{tabular}{llll} 
& Hyvä & Keskiverto & Heikko \\
\hline Liikevaihto (€) & 689290 & 519822 & 411145 \\
Kulut/liikevaihto (\%) & 69 & 66 & $\mathbf{8 1}$ \\
Velat/liikevaihto (\%) & $\mathbf{1 6 4}$ & 132 & 141 \\
Kassavarat/liikevaihto (\%) & 7,7 & 0,7 & $\mathbf{0}$ \\
Tulos/liikevaihto (\%) & 10,9 & 16,5 & $\mathbf{6 , 4}$ \\
Maitotulo/liikevaihto (\%) & 68,6 & 65,4 & $\mathbf{5 3 , 1}$ \\
Maataloustuet/liikevaihto (\%) & 24,5 & 26,1 & $\mathbf{3 0}$
\end{tabular}

Taulukosta 3 nähdään tutkimustilojen suurimpia menoja. Menot on kerätty tiloille laadituista kassabudjeteista ja verrattu niitä vuoden 2015 arvioituun puhtaaseen maitotuloon ilman maidon pohjoista tukea. Menoerät on päivitetty budjetteihin ajan tasalle tuotteiden markkinahintojen mukaisesti. Esimerkiksi rehujen hinnat ovat pudonneet vuodesta 2013 noin $10 \%$, polttoaineiden hinnat ovat laskeneet $20 \%$ ja lannoitteiden hinnat taas nousseet noin $10 \%$. Tuotteiden hintoja arvioidessa on hyödynnetty vuoden 2015 tammikuun markkinahintoja. Menot on esitetty siinä suuruusjärjestyksessä tutkimustiloilta saamien tietojen mukaan.

TAULUKKO 3. Tilojen suurimmat menoerät suhteessa maitotuloon

\begin{tabular}{llll} 
& Hyvä & Keskiverto & Heikko \\
\hline Rehukustannus/maitotulo (\%) & $\mathbf{3 5 , 4}$ & 33,3 & 34,2 \\
Rahoitusmenot/maitotulo (\%) & 29,5 & 31,7 & $\mathbf{4 1 , 4}$ \\
Koneiden kustannukset/maitotulo (\%) & 17,8 & 14,5 & $\mathbf{2 4 , 5}$ \\
Urakointimenot/maitotulo (\%) & 0 & $\mathbf{1 9 , 5}$ & 7 \\
Yksityistalouden menot/maitotulo (\%) & 12 & 12,5 & $\mathbf{1 5 , 6}$ \\
Kasvinviljelyn menot/maitotulo (\%) & $\mathbf{9 , 6}$ & 9,4 & 9,4
\end{tabular}

\section{Johtopäätökset}

Tutkimuksen alussa lähtö- olettamana oli, että maidontuottajat eivät budjetoi. Tämä olettamus osoittautui paikkaansa pitäväksi tutkimustulosten perusteella. Ainoastaan yksi tila oli budjetoinut aikaisemmin, joten budjetoijat ovat satunnaisia. Yrittäjillä oli kiinnostusta asiaa kohtaa ja suurin osa tiloista aikoi ottaa kassabudjetointityökalun heti käyttöön. Tämä on mielestäni erittäin positiivinen asia. Työn tärkein johtopäätös onkin, että lypsykarjatilojen kannattaa aloittaa budjettien laatiminen viimeistään nyt, koska maatalouden markkinatilanne Suomessa ja maailmalla on muuttunut entistä epävakaammaksi. On entistä tärkeämpää, että yrittäjät ovat itse parhaiten selvillä oman yrityksensä taloudellisesta tilanteesta. Tällöin heillä on paremmat mahdollisuudet reagoida ja selvitä vaikeista ajoista.

Maksuvalmiuden ongelmakohtia kartoittaessa päällimmäiseksi nousi yrittäjien rahan käytön suunnitelmallisuus ja ostokäyttäytyminen. Heikoilla tiloilla tämä näkyi esimerkiksi harkitsemattomissa käteisostoissa. Ostokäyttäytyminen tapahtui periaatteella ostetaan ensin ja mietitään sitten riittävätkö rahat tulevaisuudessa. Tällaista toimintaa oli havaittavissa etenkin yllättävien konerikkojen osalta, kuten jo yhteenvedosta kävi ilmi. Tässä kannattaisi ottaa mallia hyvän luokan tiloilta, eli informoida 
yhteistyökumppaneita ja rahoittajaa tilanteesta, tarkastella tapaus tilannekohtaisesti ja suunnitella oston rahoitus vaarantamatta yrityksen kassan tilannetta tulevaisuudessa. Lisäksi tulojen ja menojen budjetoinnilla ja budjettia päivittämällä olisi helppo tarkastella äkillisten menojen vaikutusta loppuvuoden kassaan.

Rahan käytön hallintaan liittyy myös oleellisesti kassavirtojen aktiivinen seuranta. Tutkimuksen pohjalta hyviksi havaittuja keinoja ovat oma- aloitteinen tilitapahtumien seuranta kuukausittain tulojen ja menojen osalta. Tätä helpottaisi ehdottomasti se, että yrityksellä ja yksityistaloudella olisi omat pankkitilinsä. Tällöin yksityistaloudella olisi omat rahavirrat ja yrityksen tiliä käytettäisiin vain yrityksen rahaliikenteeseen. Tällöin tulojen ja menojen budjetointi on myös paljon helpompaa, jolloin yritystilin tilitapahtumia voidaan käyttää "toteutuneena" budjettina ja verrata niitä laadittuun budjettiin. Lisäksi yksityistalouden menojen osuus on helpompi arvioida omalta tililtään. Osa tutkimustilallisista onkin jo avannut erillisen tilin yksityistaloudelleen tilavierailujen jälkeen, joten tämän työn positiivisia vaikutuksia on havaittavissa jo ennen sen valmistumista.

Yrittäjät seurasivat tulojaan ja menojaan myös arvolisäverojen avulla palautuksien ja maksatusten osalta. Tällä tavoin voi myös hallita yrityksen maksuvalmiutta. Etenkin kuukausi alv menettelyssä oleva yrittäjä oli tähän käytäntöön erittäin tyytyväinen. Valtaosa lypsykarjatilallisista on kuitenkin vielä vuosittaisessa arvonlisäveromenettelyssä. Yrittäjien kannattaisikin harkita siirtymistä esimerkiksi kuukausittaiseen tai neljännesvuosittaiseen arvonlisäveromenettelyyn, jolloin he pystyisivät seuraamaan saataviaan tai tilitettäviään tuloja ja menoja lyhyemmällä aikavälillä. Tämä lisäisi myös rahankierron nopeutta yritysten sisällä, eikä esimerkiksi investointi vuoden suuret alv palautukset seisoisi verottajan tilillä seuraavaan vuoteen, vaan tulisivat takaisin yrityksen kassaan. Tämä voisi parantaa tilojen maksuvalmiutta myös jossain määrin.

Rahan käytön suunnitelmallisuuden ja sen aktiivisen seurannan pohjalta yrittäjät voivat pyrkiä luomaan kassapuskureita esimerkiksi kasvukausien ajaksi, jolloin rahaa on tiloilla vähiten käytettävissä. Tämän kaikki yrittäjät olivat omaksuneet, mutta vain harvat pystyivät sitä toteuttamaan johtuen heikosta maksuvalmiudesta. Budjetin avulla myös kassapuskureiden laadinta on helpompaa. Kassapuskurina voi toimia myös luotollinen käyttötili, jonka luottorajaksi voidaan soveltaa esimerkiksi kuukauden maitotilin määrää tai tiettyä osaa siitä. Tämä olikin yleinen käytäntö tutkimustiloilla. Luotollisen tilin käytössä tulisi pyrkiä kuitenkin siihen, että saldo saisi painua miinukselle ainoastaan tarvittaessa. Tilin saldon ollessa aina pakkaselle sen tuoma hyöty vähenee, koska lainastahan täytyy maksaa korkoa. Ja sehän kertoo myös siitä, että yrityksen maksuvalmius on jatkuvasti heikkoa, mikä taas vaikuttaa pitkällä tähtäimellä negatiivisesti myös kannattavuuteen ja vakavaraisuuteen.

Verkostoituminen on tämän päivän muoti- ilmiö. Näin on myös maataloudessa. Tutkimustulosten pohjalta voi tehdä johtopäätöksen, että verkostoitumisesta ja aktiivisesta yhteydenpidosta alan muihin toimijoihin on hyötyä myös maksuvalmiuden hallinnassa. Hyvään luokkaan sijoittuvat yrittäjät olivat aktiivisia yhteydenpidon osalta esimerkiksi rahoittajaan, neuvontaan, kauppoihin ja muihin viljelijöihin. Yllättävien menojen kohdalla he ovat heti yhteydessä esimerkiksi konerikon vaikutuksen piirissä oleviin toimijoihin, kuten pankkiin, josta voidaan tarvita mahdollista lyhytaikaista rahoitusta tilanteeseen. Tämä on erittäin hyvä riskien hallinnan keino, jota kaikkien viljelijöiden kannattaa noudattaa tuotantosuunnasta riippumatta. Ongelmien kanssa ei aina tarvitse painia yksin.

Yksittäisistä menoista haluan nostaa esiin rahoitusmenot, joissa tilojen välillä oli merkittäviä eroja budjettia tarkasteltaessa. Rahoitusmenojen suuruus riippuu paljon lainojen maksuohjelmista, korkotasoista ja vieraan pääoman määrästä. Tässä tutkimuksessa suurin vaikuttava tekijä rahoitusmenoihin ovat ennemminkin maksuohjelmat kuin lainan määrä. Tätä voidaankin peilata viljelijöiden rahan käyttöön ja ostokäyttäytymiseen, koska suunnittelemattomia ostoja tekevät yrittäjät joutuvat myös käyttämään enemmän lyhennyslykkäyksiä kassavarojen vähentymisen myötä. Eli suunnitellussa maksusuunnitelmassa ei voida pysyä. Lisäksi heillä on usein liian tiukat maksuohjelmat suhteessa maksukykyyn. Maksuohjelmat laaditaan yleensä yrittäjän maksukyvyn mukaan arvioiden tilan tulevaisuuden tuottoja yhdessä rahoittajan ja yrittäjän kesken, joten sen pitäisi olla lähellä totuutta. Eli johtopäätöksenä, että yrittäjän pitäisi suhteuttaa rahan käyttönsä maksuohjelmien mukaisesti, jolloin myös kassa pysyisi paremmassa kunnossa ja rahoittaja näkisi yrittäjän kyvyt talouden hoitoon positiivisena. Toki aina tämä ei onnistu edes hyvän maksuvalmiuden omaavilla tiloilla johtuen esimerkiksi erilaisista kriiseistä ja markkinoiden muutoksista, joihin yrittäjä ei voi itse vaikuttaa. Tällöin tarvitaan joustoa myös rahoittajan puolelta maksuohjelmien suhteen. Esimerkkinä vuoden 2015 maitokriisi, jolloin kaikki tutkimustilalliset joutuivat käyttämään lyhennyslykkäyksiä. Tämä kertoo myös rahoittajan ymmärryksestä ja hyvästä suhtautumisesta tilojen toimintaa kohtaan. 
Muita hyödyllisiä ja enemmän pitkäaikaisen taloudenhallinnan keinoja tutkimustulosten perusteella ovat investointien poistojen käytön suunnittelu ja verosuunnittelu. Poistojen suhteuttaminen lainojen lyhennystahtiin on suotavaa ja verosuunnittelussa kannattaa hyödyntää mahdollista nettovarallisuutta tulonjaossa sekä tulonjakoa puolisoiden kesken. Nämä keinot yrittäjät olivat hyvin omaksuneet. Esimerkiksi verosuunnittelua kannattaa harjoittaa usean vuoden ajalle. Samalla täytyy suunnitella poistojen käyttöä lainojensa kanssa sekä tällöin tulee suunniteltua tilan taloutta ja tulevaisuutta kokonaisuutena. Verosuunnittelun tarkoituksena ei ole kiertää veroja, vaan suunnitella yritykselleen mahdollisimman tasainen verotus tulevaisuudessa ilman suurempia notkahduksia suuntaan tai toiseen. Tämä vaikuttaa positiivisesti myös yritysten maksuvalmiuteen.

Yhteenvetona voi todeta, että kassavirtojen hallinta on usean eri tekijän summa. Yritystaloutta on tarkasteltava lyhyellä ja pitkällä tähtäimellä ja siihen tarvitaan osaamista ja ammattitaitoa. Lisäksi oman toiminnan arvioiminen ja yhteistyön merkitys nousee suureen rooliin. Tässä tutkimuksessa kartoitetut ongelmakohdat ovat samansuuntaisia kuin Halosen ja Rissasen asiantuntijahaastatteluissa tuli esille. Lisäksi asiantuntijoiden lausunnoista käy ilmi budjetoinnin merkitys ja etenkin menojen hallinnan ja ostokäyttäytymisen vaikutus tilan maksuvalmiuteen. Voisikin todeta, että tämä tutkimus vahvisti nämä lausunnot ja pureutui oleellisimpien ongelmien sisälle etsien niihin ratkaisukeinoja.

\section{Lähteet}

Halonen, M. 2014. Kiuruvesi, 24. Marraskuu 2014.

Kiviranta, T. 2013. Maaseuduntulevaisuus.fi. [Online] 21. Lokakuu 2013. [Viitattu: 17. Joulukuu 2014.] http://www.maaseuduntulevaisuus.fi/maatalous/maidontuotanto-kasvussa-tilojen-v\%C3\%A4henemisest\%C3\%A4huolimatta-1.49289.

Tuomi, J ja Sarajärvi, A. 2012. Laadullinen tutkimus ja sisällön analyysi. Vantaa : Hansaprint Oy, 2012. Vuorisalo, S2014. maataloustilastot.fi. [Online] 23. Toukokuu 2014. [Viitattu: 17. Joulukuu 2014.] http://www.maataloustilastot.fi/alueittainen-maidontuotanto. 